\title{
Branding in B2B Marketing
}

\author{
Monireh Akbari \\ Islamic Azad University, Birjand Campus, Birjand, Iran \\ E-mail: mnr.akbari2196@gmail.com
}

\begin{abstract}
Hossein Hakimpour
Assistant Professor, Department of Management, Islamic Azad University

Birjand Branch, Birjand, Iran
\end{abstract}

Received: December 12, 2017

Accepted: May 1, 2018

Published: June 10, 2018

doi:10.5296/ijim.v3i1.13321

URL: https://doi.org/10.5296/ijim.v3i1.13321

\begin{abstract}
As far as marketing is concerned, brands have received much attention and become a key player in modern society. In fact, they are everywhere and they have penetrated all spheres of our life including economic, social, cultural, sporting, even religious aspects of our life.

In spite of their pervasiveness and widespread use, brands have been also the subject of growing criticism (Klein, 1999). Brands are intangible assets that produce added benefits for the business. This issue pertains to the domain of strategic brand management whose focal concern is how to create value with proper brand management. Branding is crucial in B2B marketing and has attracted much attention. Business sectors have to differentiate themselves from the competitors, not only on the basis of their product but also on the basis of aspects such as management competencies, technologies, services and infrastructure.

Industrial product marketers, whether large or small, should formulate their branding strategies effectively so that they can compete with the global competitors. The purpose of the current paper is to briefly discuss branding process. Moreover, it also examines the issues involved in the branding of B2B organizations. Finally, the paper concludes by introducing the strategies for business branding in the contemporary global environment. Paper is based on secondary information sources, ranging from print to electronic media.
\end{abstract}

Keywords: Branding, B2B, Global, Strategies, Industrial product, Marketer 


\section{Background}

\section{What is a Brand?}

Brand equity, brand management, brand awareness, brand positioning, brand culture, brand strategy, brand functions and brand environment are all conjugated of one single noun: brand. The word "brand" finds its origin in ancient times where livestock, criminals or slaves got permanently marked with a branding iron to identify ownership. (http://oxforddictionaries.com).

According to Ries and Ries (2000) a brand is a special word in the mind of consumers: a noun, with the power to influence purchasing behavior.

In the same order of identifying and possession, the American Marketing Association (AMA) defined a brand as: "A name, term, sign, symbol, or design, or a combination of them, intended to identify the goods or services of one seller or group of sellers and to differentiate them from those of competitors" (AMA, www.marketingpower.com).

Keller (2008) adopts a wider perspective, making a distinction between the brand definition as set by AMA and the industry's conceptulaization of branding. Keller (2008) adds tangible and intangible brand elements, rational and emotional brand elements, and symbolic brand elements which differentiate and identify a brand. As a result, it can be argued that Keller's definition is taken from a more holistic point of view: "A brand is, therefore, more than a product, because it can have dimensions that differentiate it in some way from other products designed to satisfy the same needs" (Keller, 2008). Van Gelder (2003) recognizes the managerial interdependencies and argues that "a brand is the translation of the business strategy into a consumer experience that brings about specific behavior".

For Kapferer (2008), the brand is a source of influence; a system of interconnected mental associations (brand image) and relationships. According to Kapferer (2008), a brand as such, exists when it has the power to influence the market acquired by its source of cumulative brand experience. The dynamics of branding and the bi-directional contingencies between the brand and the market makes the brand a living system which is built around three anchor points: (1) product and service, (2) name and symbols, (3) concept.

Kotler and Pfoertsh (2006) adopted a holistic paradigm and further argued that a brand is a promise to the consumer to whom the brand has formed a set of perceptions about a product, service or business. Consequently, the brand holds a distinctively influential position in customer's mind where the brand represents a short-cut of attributes, benefits, beliefs and values based on past experiences, associations and future expectations. Finally, it is the brand that differentiates, reduces complexity, and simplifies the decision-making process.

\section{What is branding?}

The area of branding has emerged to a top priority for management in the last 20 years.

In fact, brands are one of the most valuable intangible assets within a firm (Keller \& Lehman, 2006). 
The brand name encompasses the years of advertising, good will, quality evaluation, product experience and other beneficial attributes the market associates with the product.

Branding can be traced back to product marketing, where the role of branding and brand management has been primarily to create differentiation and preference for a product or service in the mind of the customer (Knox \& Bicherton, 2003).

For Strizhakova and Price (2008), Sirvastava and Gregory (2010) and Kapferer (2008) branding strategies are developed by organization, for the product, in order to position and identify the brand with positive product benefits to attract potential customers, create brand awareness and to increase profitability .

Knox and Bickerton (2003) continue, "The development of product branding over the past 30 years is characterized by layers of added value built around the core functionality of the product or service to create and maintain distinction in a particular market."

B2B branding has emerged as a top management priority in the last decade due to the growing realization that brands are one of the most valuable intangible assets that firms have. In B2B branding, firms are differentiated on the basis of their sincerity and commitment in providing quality services and their ability to create emotional branding with the customer. Over the past decade, a considerable amount of research has shown that brand names can help customers recall important product Information. For example, the association from a brand name to a product category helps a person recognize potential usage situations. This conceptualization of a brand name as a recall prompt has been used to hypothesize how people create consideration sets, evaluate alternatives, and make decisions about the appropriateness of brand extension (e.g. Keller, 1998).

B2B branding can function as more than associative cues for information retrieval. Branding can also serve as predictive cues a bout performance. The predictive value of brand names is one of the primary reasons the brand extension strategy is so persuasive. Using a successful family brand name to identify a new product enhances customer expectations about the performance of the new product, which in turn leads to increased trial and/or reduced promotional costs (Smith \& Park, 1992; Sullivan, 1992).

\section{Introduction}

\subsection{B2B Marketing}

B2B marketing consists of all activities involved in the marketing of products and services to organizations which may be commercial, profit or nonprofit institutions, government agencies or resellers that use products or services in the production of consumer or industrial goods and services, and to facilitate the operations of the enterprise.

\subsection{B2B Branding}

Branding means much more than just giving a brand name and signaling to the outside world that such a product or service has been stamped with the mark and imprint of an organization. It requires a corporate long-term involvement, a high level of resources and skills. Brands are 
a direct consequence of the strategy of market segmentation and product differentiation. As companies seek to better fulfill the expectations of specific customers, they concentrate on providing the latter, consistently and repeatedly, with the ideal combination of attributes-both tangible and intangible, functional and hedonistic, visible and invisible - under viable economic conditions for their business. Companies want to stamp their mark on different sectors and set their imprint on their products. It is no wonder that the word "brand" also refers to the act of burning a mark into the flesh of an animal as a means to claim ownership of it.

The first task in brand analysis is to define precisely all that the brand injects into the product (or service) and how the brand transforms it:

- What attributes materialize?

- What advantages are created?

- What benefits emerge?

- What ideals does it represent?

To develop trust, confidence and loyalty in its products, every business has to develop and maintain a distinct identity, image or reputation. Only then is it able to distinguish itself and its products from those of its competitors. It must also, at the same time, provide a mechanism for linking the provider of a product to the valuable business assets of trust and good will. Business achieve this mostly through branding.

Branding plays a pivotal role in the marketing strategy of differentiating products from those of rivals and in developing longer - term positive - and often emotional - relationships with customers by communicating an assiduously nurtured image or reputation. Every business must woo customers to move them quickly from brand awareness, via brand recognition, to brand insistence, a point at which the customer refuses to accept alternatives and is willing to pay an even higher premium for the desired branded product.

\section{Branding Process in B2B Marketing}

Brand procedures and branding principles are a necessity to establish an effective brand campaign.

Kotler and Pfoertsh (2006) argue that successful branding relies on the utmost importance of five branding principles, namely:

Consistency: This is one of the most important branding principles for any organization. To become consistent, organizations should leverage this with a holistic approach, far beyond the product or brand. It affects each and every single contact point between the organization and its stakeholders

Clarity: Clarity makes the brand more tangible and understandable. Clarity is based on the vision, mission, core values and core competencies of the organization. These should be easy to communicate and understand in such a way, that it enables stakeholders to position the 


\section{Macrothink}

brand relevance in their mind.

Continuity: Stakeholders (people) trust the brand that it will deliver whatever it promised based on past experience, they know what to expect. Hence, continuity is an important principle to develop brand equity and trust on the long term.

\section{Visibility:}

Brand visibility is all about increasing brand exposure and developing brand awareness.

Authenticity: Brand authenticity is the undisputed origin of behaviorism of all organizational members with the objective of creating the feeling for the customer to own, use or direct a unique valuable product or service.

Brand building requires a long term vision and planning, supported by top management and executed thoroughly across all managerial processes.

To embed brand consistency and brand clarity in the strategy process Kotler and Pfoertsch (2006) argue to follow a five-step brand building process: (1) brand planning, and (2) brand analysis, (3) brand strategy, (4) brand building, and (5) brand audit.

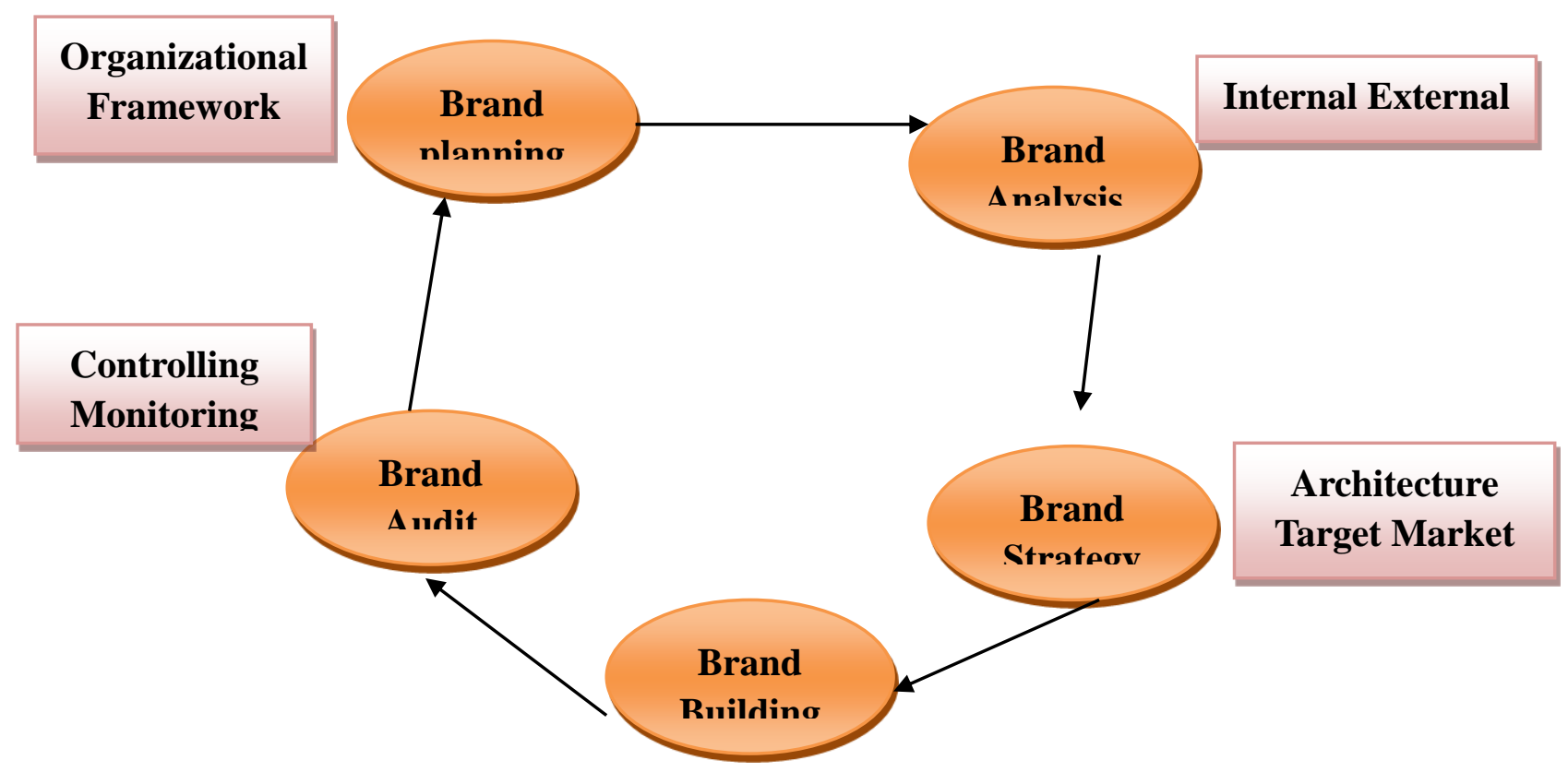

\section{Marketing plan \\ Implementation}

Figure 1. Sequence of the brand building processes

Source: Kotler and Pfoertsh, 2006. 


\section{Macrothink}

To develop the brand and brand leadership and gain sustainable market share, organizations need to manage the brand carefully in the appropriate direction.

For this reason Kapferer (2008) stated that the brand must be: (1) embodied in products, services and places; (2) put into practice by people at contact points; (3) activated by needs and behaviors; (4) communicated; (5) distributed.

The principles of strong brands are captured in the brand report card of Keller (2000). After Keller identified ten characteristics that the world's strongest brands share, he constructed a systematic and uniform manner of valuing brand performance. Although it is developed as audit tool, the characteristics can be seen as a set of branding principles which should be in place. The brand report card is helpful to monitor the brand performance and brand comparison (Keller, 2000).

The ten characteristics are stated in the imperative mood and need to be rated between 1(extremely poor) and 10- (extremely good), the original characteristics are 1-on-1 copied (Keller, 2000):

1) "The brand excels at delivering the benefits customers truly desire.

2) The brand stays relevant.

3) The pricing strategy is based on customer's perceptions of value.

4) The brand is properly positioned.

5) The brand is consistent.

6) The brand portfolio and hierarchy make sense.

7) The brand makes use of and coordinates a full repertoire of marketing activities to build equity.

8) The brand's managers understand what the brand means to costumers.

9) The brand is given proper support, and that is sustained over the long run.

10) The company monitors sources of brand equity."

As Keller admits it is tremendously difficult to maximize all ten characteristics, still it is of vital importance to balance all ten. Due to the synergistic effect, excelling at one characteristic makes it less difficult to excel as well on others (Keller, 2000).

\section{Brand Functions}

Kapferer (2008) mentions that before the 1980's there was a different approach towards brands. "Companies wished to buy a producer of chocolate or pasta: after 1980, they wanted to buy Kitkat or Buitoni. This distinction is very important; in the first case firms wish to buy production capacity and in the second they want to buy a place in the mind of the customer" (Kapferer, 2008). In other words, the shift in focus towards brands began when it was understood that they were something more than mere identifiers. 


\section{Macrothink}

\subsection{Brand Functions from Customer Perspective}

Brands, according to Kapferer (2008) serve eight functions: Identification, Practicality, Guarantee, Optimisation, Characterization, Continuity, Hedonistic, Ethical.

The first two are mechanical and concern the essence of the brand: "to function as a recognized symbol in order to facilitate choice and to gain time"; the next three are for reducing the perceived risk; and the final three concern the pleasure side of a brand. He argues that brands perform an economic function in the mind of the consumer, "the value of the brand comes from its ability to gain an exclusive, positive and prominent meaning in the minds of a large number of consumers." Therefore branding and brand buiding should focus on developing brand value.

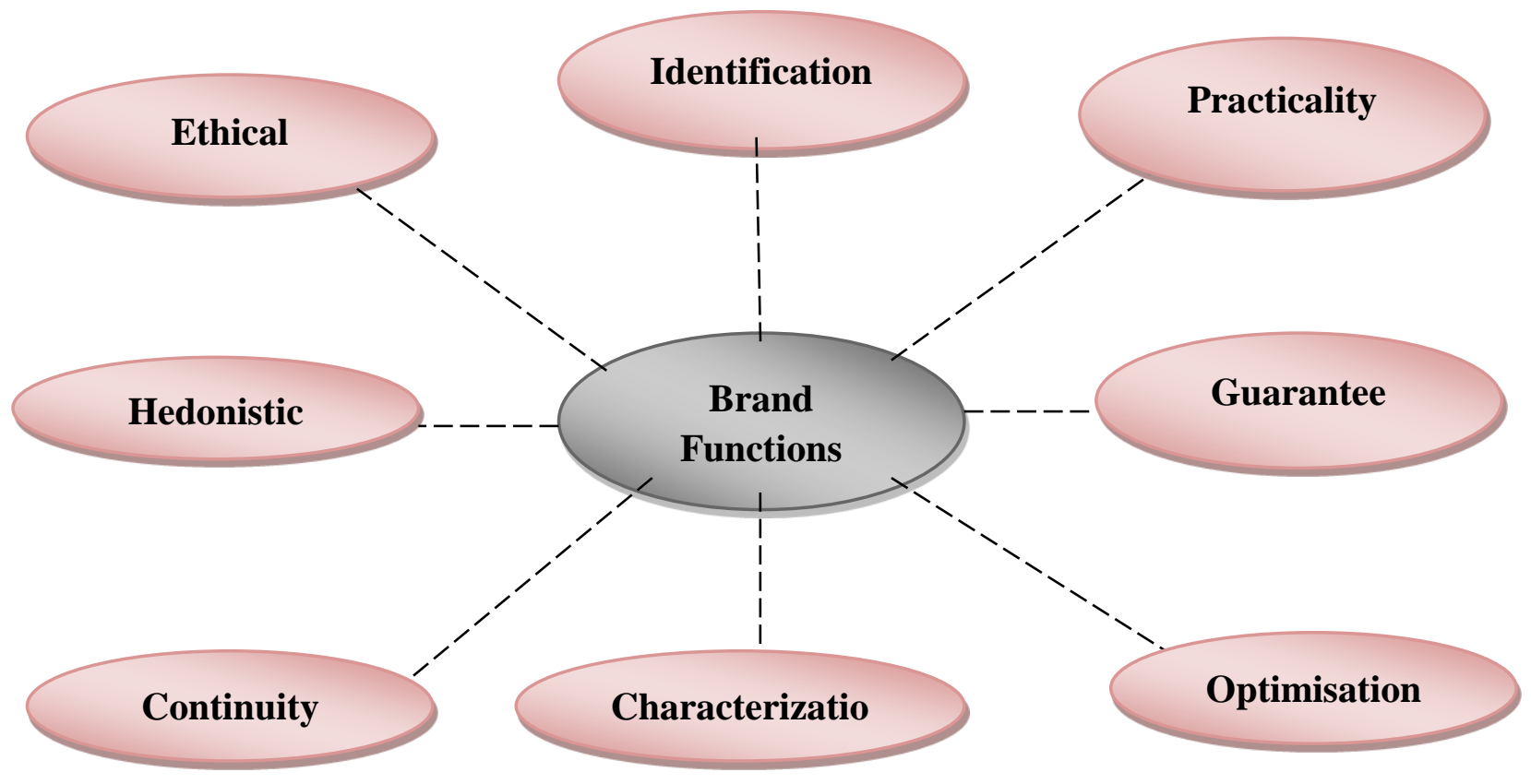

Figure 2. The functions of the brand for the customer

Source: Kapferer, 2008.

\subsection{Brand Functions from Company Perspective}

Allocation of organizational resources to release brand potential plays on important role to establish a brand leadership position. Building a strong sustainable brand can lever long term business development tremendously. From a brand function perspective Kotler and Pfoertsh (2006) have outlined eight different roles of the brands to conquer a unique position in the mind of stakeholders. 


\section{Macrothink}

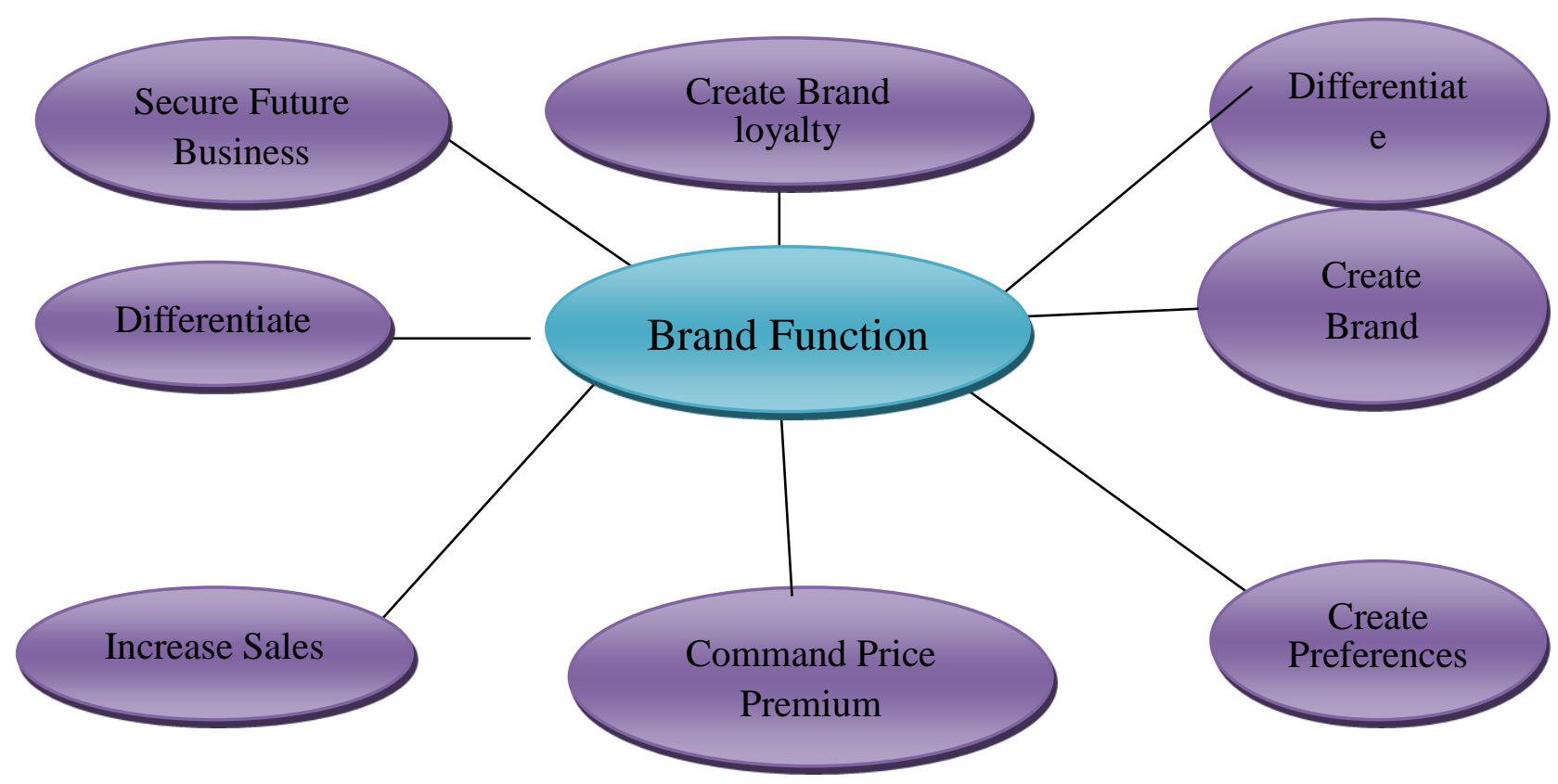

Figure 3. The role of brands from company perspective

Source: Kotler and Pfoertsh, 2006.

\section{Umbrella Branding}

Brand manufacturers are increasingly trying to leverage their brands by cross-promoting and cross-selling different product categories under an umbrella brand (Kumar et al., 2008). The introduction of new products by labeling more than one product with a single brand name reaches a share of over $90 \%$ in many fast moving consumer good product categories (Sattar et al., 2005).

Umbrella branding is a form of economies of scope, as it economizes on the costs of creating a new brand (Cabral, 2007). An umbrella brand can help consumers in their decision-making for new products when quality information is missing.

Brand extensions work because all products under the umbrella contribute to the brand's reputation.

Umbrella branding is also known as family branding is one of the marketing practices involving the use of a single brand name for the sale of two or more related products or services.Umbrella branding is generally practiced by companies with positive brand equity which means a value of a brand in a certain marketplace. All products exercise the same means of naming and lack added brand names or symbols.

This marketing practice is different from brand extension in that umbrella branding involves the marketing of analogous products, rather than differentiated products, under one brand name. 


\section{Co-Branding}

Co-branding is fundamentally a response to the need for continual growth. However, whereas yesterday companies would have sought at any price to acquire the new competences that were missing and restricting their ability to innovate, today they seek to find a partner with which to co-create. This is the era of alliances, partnerships and the networked economy, where each party retains its specialization and its key competence, and utilities those of others to the fullest extent.

When trying to grow, the brand can reach the limits of its own identity and its specificity: it therefore has need of an ally to fill the gaps where it is not competent or legitimate.

Co-branding is necessary to increase the chances of success for a brand's extension beyond its original market. It is also necessary when the brand's image makes it difficult to communicate with a particular target. Co-branding makes it possible to develop a product line that is often sold in a separate distribution channel and to move up a level. Co-branding is a response to the fragmentation of the market and the emergence of communities. Co-branding sometimes aims to provide a buzz around the brand among opinion leaders, to create an image.

Finally, Co-branding is the visible - confidence-inspiring - sign of a brand union.

\section{Brand Building Strategy}

The brand strategy plan specifies the direction and scope of the brand over the long term to maintain and build sustainable competitive advantage over the competition (Arnold, 1992). Van Gelder (2003) argues that brand strategy starts with an accurate understanding of the business strategy to ensure strategic consistency. Corporate strategy and brand strategy should be aligned in order to create stakeholder value (Van Gelder, 2003). Brand strategy is based on the brand core, brand values and brand associations using building blocks as brand mission, brand architect, brand positioning, brand value proposition, brand promise and brand personality (Kotler \& Pfoertsch, 2006).

Brand strategy itself, is the process whereby a company identifies which brand elements are necessary to create the appropriate and feasible brand proposition to the target group (Kotler \& Pfoertsh, 2006). As a consequence, brand strategy should involve a holistic approach throughout the organization and embraces employee's roles as being ambassadors of the brand. Within the strategy process brand elements, brand architecture, brand identity and brand positioning fulfill an important function.

Aaker (2000) has created a brand leadership model where the brand manager fulfills a strategic and visionary role. Brand strategy needs to be consistent with the business strategy, corporate vision and culture (Aaker, 2000). To build and become a strong brand, Aaker (2000) distinguishes four tasks, which organizations should achieve:

1) Organizational structure and processes to build an effective and efficient brand organization.

2) Brand architecture to guide and develop a strategic brand direction. 


\section{Macrothink}

3) Brand identity and brand position to differentiate the brand(s) within the appropriate markets.

4) Brand building programs to plan, create, develop, implement, execute and monitor effective brand building programs.

An effective brand building strategy will help firms increase reputation, relevance and visibility.

\section{Top brand building strategies:}

1) Content marketing

2) Develop visible experts

3) Cultivate prestigious teaming partners

4) Seek high profile clients and case stories

5) Dominate the social media space, appropriately

\section{a. Content marketing}

Think educational rather than promotional

Potential clients will develop trust over time

$>$ Share valuable content to build your brand

$>$ Highlights expertise

\section{b. Develop visible experts}

$>$ Few experts become visible

$>$ The strength of an expert's personal brand will transfer to the firm via "halo effect"

$>$ Give "technical professionals" a platform to sell

\section{c. Cultivate prestigious partners}

Partner with prominent organizations

$>$ Partnering is not the same a sponsoring

$>$ Conduct a research project or start an educational program

Leverage relationships to build online traction

\section{d. Seek high profile clients and case stories}

Develop and invest in a consistent strategy

$>$ Produce and share results

$>$ Focus on capturing benefits, not services 


\section{e. Dominate the social media space}

$>$ Many firms are using social media, but inappropriately

$>$ No different than networking. Who should you connect with?

$>$ It is still possible to become a major online voice within your target group.

\section{What is the best brand building strategy?}

$>$ Combining several top strategies

$>$ No strategy is effective unless it's implemented

> No implementation is successful unless reviewed and adjusted.

\section{How strong is your brand?}

\section{Reputation $\times$ Visibility $=$ Brand Strength}

The better and more focused the reputation and the greater the visibility within the target client group, the more valuable the brand.

\section{Previous Studies}

Wendy C. Wong (2009), in research on "B2B and B2C Marketing: organizing to maximize brand value" says that "when a brand operates in both a B2B and B2C market, companies often create marketing departments under leadership to address each market separately. These marketing silos often miss out on opportunities for synergies that would drive value for the organization. IMC (integrated marketing communications) could be the solution by the providing a new organizational model for synergistic brand management ,media relations and campaign messaging _thus optimizing all market opportunities across business models.”

Tommi Mahlamaki et al. (2014) in their research on "Branding as an opportunity of SMEs' internationalization strategy in B2B market" say that "Branding theory has its origins in the consumer product markets. The brand is presented as market signal targeted mostly to the end consumers and enabling them to save time by guaranteeing a certain level of quality ,simplifying their choices, and answering to specific needs. The modularity can be helpful for a SME not only creating economies of scale and economies of scope but also in brand creation."They argue that brand creation is important for internationalizing SME in the B2B market and that modularity can be used in brand creation.

Mariana Gomes et al. (2016) did research on "Determinants of brand relevance in a B2B service purchasing context" concluded that attributes related with brands matter even in B2B rational decision _ making process. However, brands are not important to all organizational buyers or in all situations .Different purchase situations and decision _maker characteristics proved to have an impact on brand relevance, namely, brand reputation ,prior purchases and brand awareness. Only firm size was not confirmed as a determinant of brand relevance in the B2B purchasing process. 
Peter J. LaPlaca (2013) in his paper on "Research priorities for B2B marketing researchers" say that "The field of $\mathrm{B} 2 \mathrm{~B}$ marketing is rapidly growing as a research focus and academic researchers have ample opportunity to conduct research with a high likelihood of publication if they focus on research topics of importance and interest and they follow accepted research methodologies." They classified research needs into "selling and sales management, global marketing, branding, B2B use of social media, innovation, sustainability, business networks, B2B services, Marketing organizations, distribution and channel management, B2B marketing theory.

Philip Kotler (2006) in his article on "B2B brand management" has some suggestion for those who are interested. He believes that "underestimating the power of brands in B2B should be stopped .Branding should be the thread running through the subject of marketing. A consistent impression should be made and a strategic brand architecture should be built. The most common brand strategy in $\mathrm{B} 2 \mathrm{~B}$ is a corporate brand in combination with a few product brands. It is essential for every brand to implement a comprehensive and adequate measurement system to gauge and guide brand success. Social branding is a great way for B2B companies to receive high marks for social responsibility. Building brand through word _of _mouth is a common approach in the industrial world. Online Branding is a crucial part of B2B brand building. It is crucial to effectively communicate the values of your brands to your own people; making sure that employees understand these values and thereby leading them to become the best ambassadors of your company and its products."

\section{Conclusion}

Nowadays, a brand reflects the quality and credibility of a firm's products or services and is characterized as a perception of the customer towards the organization. As a result, given the significance of brands, more companies are focusing on creating strategy to create value and differentiation in today's competitive environment. As previously pointed out, the brand and what it presents is the most important asset for many companies. From this perspective, possessing strong and memorable brand brings about more benefits, since powerful brands deliver value to both the customer and the organization. Thus, it can be concluded that strong brands not only benefit the firm and the product but they also offer benefit to the customer. The reason lies in the fact that a strong brand is usually associated to quality and trust, and, as a result, a customer will feel more confident in buying the product.

In sum, a brand is more than just a word or symbol used to identify products and companies; it stands for the immediate image, emotions, or message people experience when they think of a company or product. A brand represents all the tangible and intangible qualities and aspects of a product or service. A strong brand represents a collection of feelings and perception about quality, image, lifestyle, and status. Strong brands create a perception in the mind of the customer that there is no other superior or equal to the product or service on the market. Strong brands promise to deliver value upon which customers and prospective purchasers can rely to be consistent over long periods of time. 


\section{References}

Aaker, D. A. (1994). Should you take your brand to where the action is? Harvard Bus. Rev. (Sept./Oct.), 135-143.

Aaker, D. A. (1996). Measuring brand equity across products and markets. California Management Rev., 38(Spring), 102-120. https://doi.org/10.2307/41165845

Aaker, D. A., \& Jacobson, R. (1994). The financial information content of perceived quality. Journal of Marketing Res., 31(May), 191-201. https://doi.org/10.2307/3152193

Aaker, D. A., \& Jacobson, R. (2001). The value relevance of brand attitude in hightechnology markets. J. Marketing Res., 38(November), 485-493. https://doi.org/10.1509/jmkr.38.4.485.18905

Aaker, D. A., \& Keller, K. L. (1990). Consumer evaluations of brand extensions. J. Marketing, 54(January), 27-41. https://doi.org/10.2307/1252171

Aaker, J. L. (1997). Dimensions of brand personality. J. Marketing Res., 34(August), 347-356. https://doi.org/10.2307/3151897

Aaker, J. L. (1999). The malleable self: The role of self-expression in persuasion. $J$. Marketing Res., 36(May), 45-57. https://doi.org/10.2307/3151914

Aaker, J. L., Benet-Martinez, V., \& Berrocal, J. G. (2001). Consumption symbols as carriers of culture: A study of Japanese and Spanish brand personality constructs. J. Personality and Psychol., 81(3), 492-508. https://doi.org/10.1037/0022-3514.81.3.492

Aaker, J. L., Fournier, S. M., \& Brasel, S. A. (2004). When good brands do bad. J. Consumer Res., 31(June), 1-16. https://doi.org/10.1086/383419

Aggarwal, P. (2004). The effects of brand relationship norms on consumer attitudes and behavior. J. Consumer Res., 31(June), 87-101. https://doi.org/10.1086/383426

Ahluwalia, R., \& Gurhan-Canli, Z. (2000). The effects of extensions on the family brand name: An accessibility-diagnosticity perspective. J. Consumer Res., 27(December), 371-381. https://doi.org/10.1086/317591

Ailawadi, K. L., Lehmann, D. R., \& Neslin, S. A. (2001). Market response to a major policy change in the marketing mix: Learning from Procter \& Gamble's value pricing strategy. $J$. Marketing, 65(January), 44-61. https://doi.org/10.1509/jmkg.65.1.44.18130

Ailawadi, K. L., Lehmann, D. R., \& Neslin, S. A. (2003). Revenue premium as an outcome measure of brand equity. J. Marketing, 67(October), 1-17. https://doi.org/10.1509/jmkg.67.4.1.18688

Ambler, T. (2004). Marketing and the Bottom Line (2nd ed.). Financial Times Prentice Hall.

Ambler, T., Bhattacharya, C. B., Edell, J., Keller, K. L., Lemon, K. N., \& Mittal, V. (2002). Relating brand and customer perspectives on marketing management. J. Service Res., 5(1), 13-25. https://doi.org/10.1177/1094670502005001003 
Anand, B. N., \& Shachar, R. (2004). Brands as beacons: A new source of loyalty to multiproduct firms. J. Marketing Res., 41(May), 135-150. https://doi.org/10.1509/jmkr.41.2.135.28670

Anderson, E. T., \& Simester, D. I. (2004). Long-run effects of promotion depth on new versus established customers: Three field studies. Marketing Sci., 23(Winter), 4-20. https://doi.org/10.1287/mksc.1030.0040

Argenti, P. L. A., \& Druckenmiller, B. (2004). Reputation and the corporate brand. Corp. Reputation Rev., 6(4), 368-374. https://doi.org/10.1057/palgrave.crr.1540005

Arnold, T. (1989). Accounting for the value of brands. Accountant's Magazine, (Feb), 12.

Azoulay, A., \& Kapferer, J. N. (2003). Do brand personality scales really measure brand $\begin{array}{lllll}\text { personality? } \quad J . & \text { Brand } \quad \text { Management, } & 11(2), & 143-155 .\end{array}$ https://doi.org/10.1057/palgrave.bm.2540162

Balachander, S., \& Ghose, S. (2003). Reciprocal spillover effects: A strategic benefit of brand extensions. J. Marketing, 67(January), 4-12. https://doi.org/10.1509/jmkg.67.1.4.18594

Barich, H., \& Kotler, P. (1991). A framework for image management. Sloan Management Rev., (Winter), 94-104.

Barone, M. J., \& Miniard, P. W. (2002). Mood and brand extension judgments: Asymmetric effects for desirable versus undesirable brands. J. Consumer Psychol., 12(4), 283-290. https://doi.org/10.1207/S15327663JCP1204_01

Besanko, D., Dubé, J. P., \& Gupta, S. (2005). Own-brand and cross-brand retail pass-through. Marketing Sci., 24(1), 123-137. https://doi.org/10.1287/mksc.1030.0043

Bhattacharya, C. B., \& Sen, S. (2003). Consumer-company identification: A framework for understanding consumers' relationships with companies. J. Marketing, 67(April), 76-88. https://doi.org/10.1509/jmkg.67.2.76.18609

Bottomley, P. A., \& Holden, S. (2001). Do we really know how consumers evaluate brand extensions: Empirical generalizations based on secondary analysis of eight studies. $J$. Marketing Res., 38(November), 494-500. https://doi.org/10.1509/jmkr.38.4.494.18901

Broniarczyk, S., \&Gershoff, A. D. (2003). The reciprocal effects of brand equity and trivial attributes. J. Marketing Res., 40(May), 161-175. https://doi.org/10.1509/jmkr.40.2.161.19222

Czellar, S. (2003). Consumer attitude toward brand extensions: An integrative model and research propositions. International J. Res. Marketing, 20(March), 97-115. https://doi.org/10.1016/S0167-8116(02)00124-6

Desai, K. K., \& Keller, K. L. (2002). The effects of brand expansions and ingredient branding strategies on host brand extendibility. J. Marketing, 66(July), 73-93. https://doi.org/10.1509/jmkg.66.1.73.18450

Dowling, G. R. (1994). Corporate Reputations. London: Kogan-Page. 
Duncan, T. (2002). IMC: Using Advertising \& Promotion to Build Brands. McGraw-Hill.

Erdem, T., \& Swait, J. (2004). Brand credibility, brand consideration, and choice. J. Consumer Res., 31(June), 191-198. https://doi.org/10.1086/383434

Folkes, V., \& Matta, S. (2004). The effect of package shape on consumers' judgments of product volume. J. Consumer Res., 31(September), 390-402. https://doi.org/10.1086/422117

Ghosh, P. K. (2006). Industrial Marketing. New Delhi: Oxford University Press.

Gomes, M., Fernandes, T., \& Brandao, A. (2016). Determinants of brand relevance in a B2B service purchasing context. Journal of Business and Industrial Marketing, 31(2), 193-204. https://doi.org/10.1108/JBIM-08-2014-0151

Gupta, S., Lehmann, D. R., \& Stuart, J. A. (2004). Valuing customers. J. Marketing Res., 41(February), 7-18. https://doi.org/10.1509/jmkr.41.1.7.25084

Gurhan-Canli, Z. (2003). The effect of expected variability of product quality and attribute uniqueness on family brand evaluations. J. Consumer Res., 30(June), 105-114. https://doi.org/10.1086/374695

Gurhan-Canli, Z., \& Batra, R. (2004). When corporate image affects product evaluations: The moderating role of perceived risk. J. Marketing Res., 41(May), 197-205. https://doi.org/10.1509/jmkr.41.2.197.28667

Henderson, P. W., Geise, J. L., \& Cote, J. A. (2004). Impression management using typeface design. J. Marketing, 68(4), 60-72. https://doi.org/10.1509/jmkg.68.4.60.42736

Hill, et al. (2005). Industrial Marketing. AITBS Publishers, Delhi.

Hoeffler, S., \& Keller, K. L. (2003). The marketing advantages of strong brands. J. Brand Management, 10(6), 421-445. https://doi.org/10.1057/palgrave.bm.2540139

Janiszewski, C., \& Meyvis, T. (2001). Effects of brand logo complexity, repetition, and spacing on processing fluency and judgment. J. Consumer Res., 28(June), 18-32. https://doi.org/10.1086/321945

Kapferer, J. (2008). Creating and sustain brand equity long term: The new strategic brand management (4th ed.). Kogan page, London.

Kapferer, J. N. (2008). The New Strategic Brand Management. Kogan-Page, London, England.

Keller, K. (2008). Strategic Brand Management: Building, Measuring, and Managing Brand Equity (3rd Ed.). Upper Saddle River, NJ: Prentice Hall.

Keller, K. L. (2001). Building customer-based brand equity: A blueprint for creating strong brands. Marketing Management, (July/August), 15-19.

Keller, K. L. (2002). Branding and brand equity. In B. Weitz, \& R. Wensley (Eds.), Handbook of Marketing (pp. 151-178). London: Sage Publications. 
https://doi.org/10.4135/9781848608283.n8

Keller, K. L. (2003). Strategic Brand Management - Building, Measuring and Managing Brand Equity. Prentice Hall of India, New Delhi.

Keller, K. L. (2003). Strategic Brand Management: Building, Measuring, and Managing Brand Equity (2nd ed.). Prentice Hall, Upper Saddle River, NJ.

Keller, K. L., \& Aaker, D. A. (1998). Corporate-level marketing: The impact of credibility on a company's brand extensions. Corp. Reputation Rev., 1(August), 356-378. https://doi.org/10.1057/palgrave.crr.1540057

Keller, K. L., \& Lehmann, D. R. (2003). The brand value chain: Optimizing strategic and financial brand performance. Marketing Management, (May/June), 26-31.

Keller, K. L., \& Sood, S. (2004). The effects of product experience and branding strategies on brand evaluations. Working paper, UCLA, Anderson School of Management.

Keller, K. L., Sternthal, B., \& Tybout, A. (2002). Three questions you need to ask about your brand. Harvard Bus. Rev., 80(9), 80-89.

Keller, K., \& Lehmann, D. (2006). Research findings and future priorities. Brands and Branding Marketing Science, 25(6), 740-759. https://doi.org/10.1287/mksc.1050.0153

Klein, N. (1999). No logo, picador, new York.

Klink, R. R., \& Smith, D. C. (2001). Threats to external validity of brand extension research. J. Marketing Res., 38(August), 326-335. https://doi.org/10.1509/jmkr.38.3.326.18864

Knox, S., \& Bickerton, D. (2003). The six convention of corporate branding. European Journal of Marketing, 37(7/8), 998-1016. https://doi.org/10.1108/03090560310477636

Kotler, P., \& Keller, K. (2009). A Framework for Marketing Management. Pearson Education Inc., Upper Saddle River, New Jersey.

Kotler, P., \& Keller, K. L. (2006). Marketing Management (12th ed.). Prentice-Hall, Upper Saddle River, NJ.

Kotler, P., \& Pfoertsch, W. (2006). B2B brand management. Berlin: Springer.

Kumar, N. (2003). Kill a brand, keep a customer. Harvard Bus. Rev., (December), 86-96.

Kumar, V., George, M., \& Pancras, J. (2008). Cross buying in retailing: Drivers and consequences. Journal of Retailing, 84(1), 15-24. https://doi.org/10.1016/j.jretai.2008.01.007

Laczniak, R. N., DeCarlo, T. E., \& Ramaswami, S. (2001). Consumers' responses to negative wordof-mouth communication: An attribution theory perspective. J. Consumer Psychol., 11(1), 57-73. https://doi.org/10.1207/S15327663JCP1101_5

LaPlaca, P. J. (2013). Research priorities for B2B marketing researchers. Revista Española de $\begin{array}{lllll}\text { Investigación en } \quad \text { Marketing } & \text { ESIC, } & \text { 17(2), }\end{array}$ https://doi.org/10.1016/S1138-1442(14)60027-9 
Maoz, E., \& Tybout, A. M. (2002). The moderating role of involvement and differentiation in the evaluation of brand extensions. J. Consumer Psychol., 12(2), 119-131. https://doi.org/10.1207/S15327663JCP1202_05

McAlexander, J. H., Schouten, J. W., \& Koenig, H. F. (2002). Building brand community. J. Marketing, 66(January), 38-54. https://doi.org/10.1509/jmkg.66.1.38.18451

Meyvis, T., \& Janiszewski, C. (2002). Consumer beliefs about product benefits: The effects of obviously irrelevant product information. J. Consumer Res., 28(March), 618-635. https://doi.org/10.1086/338205

Meyvis, T., \& Janiszewski, C. (2004). When are broad brands stronger brands? An accessibility perspective on the formation of brand equity. J. Consumer Res., 31(September), Forthcoming.

Mizik, N., \& Jacobson, R. (2003). Trading off value creation and value appropriation: The financial implications of shifts in strategic emphasis. J. Marketing, 67(January), 63-76. https://doi.org/10.1509/jmkg.67.1.63.18595

Moore, E. S., Wilkie., W. L., \& Lutz, R. J. (2002). Passing the torch: Intergenerational influences as a source of brand equity. J. Marketing, 66(April), 17-37. https://doi.org/10.1509/jmkg.66.2.17.18480

Moreau, P., Lehmann, D. R., \& Markman, A. P. (2001). Entrenched knowledge structures and consumer response to new products. J. Marketing Res., 38(February), 14-29. https://doi.org/10.1509/jmkr.38.1.14.18836

Naik, P. A., \& Raman, K. (2003). Understanding the impact of synergy in multimedia communications. J. Marketing Res., 40(November), 375-388. https://doi.org/10.1509/jmkr.40.4.375.19385

Nail, P. A., Raman, K., \& Winer, R. S. (2005). Planning marketing-mix strategies in the presence of interaction effects. Marketing Sci., 24(1), 25-34. https://doi.org/10.1287/mksc.1040.0083

Pauwels, K., Hanssens, D. M., \& Siddarth, S. (2002). The long-term effects of price promotions on category incidence, brand choice, and purchase quantity. J. Marketing Res., 39(November), 42-439. https://doi.org/10.1509/jmkr.39.4.421.19114

Putsis, W. P. Jr., \& Bayus, B. L. (2001). An empirical analysis of firms' product line decisions. J. Marketing Res., 38(February), 110-118. https://doi.org/10.1509/jmkr.38.1.110.18830

Rao, V. R., Agrawal, M. K., \& Dahlhoff, D. (2004). How is manifested branding strategy related to the intangible value of a corporation? J. Marketing Forthcoming. https://doi.org/10.1509/jmkg.68.4.126.42735

Reeder, et al. (2005). Industrial Marketing, Analysis, Planning and Control. PHI, New Delhi.

Ries, A., \& Ries, L. (2000). The 22 Immutable Laws of Branding. London: Profile Books Ltd. 


\section{Macrothink}

International Journal of Industrial Marketing

ISSN 2162-3066

2018, Vol. 3, No. 1

Rust, R. T., Lemon, K. N., \& Zeithaml, V. A. (2001). Driving Customer Equity: How Customer Lifetime Value is Reshaping Corporate Strategy. New York: Free Press.

Schmitt, B. H. (2003). Experience Management: A Revolutionary Approach to Connecting with Your Customers. John Wiley \& Sons, Hoboken, NJ.

Smith, D. C., \& Park, C. W. (1992). The effects of brand extensions on market share and advertising efficiency. J. Marketing Res., 29(August), 296-313. https://doi.org/10.2307/3172741

Srivastava, R., \& Gregory, T. (2010). Managing Brand performance: Aligning positioning, execution and experience. Journal of brand management, 17(July), 765-471. https://doi.org/10.1057/bm.2010.11

Steenkamp, J. B., Batra, R., \& Alden, D. (2003). How perceived brand globalness creates brand value. J. International Bus. Studies, 34, 53-65. https://doi.org/10.1057/palgrave.jibs.8400002

Strizhakova, Y., Coulter, R., \& Price, L. (2008). The meanings of branded products: A cross national scale development and meaning assessment. International Journal of Research in Marketing, 25(2), 82-93. https://doi.org/10.1016/j.ijresmar.2008.01.001

Swaminathan, V., Fox, R. J., \& Reddy, S. K. (2001). The impact of brand extension introduction on choice. J. Marketing, 65(October), 1-15. https://doi.org/10.1509/jmkg.65.4.1.18388

Tavassoli, N.T., \& Han, J. K. (2002). Auditory and visual brand identifiers in Chinese and English. J. International Marketing, 10(2), 13-28. https://doi.org/10.1509/jimk.10.2.13.19531

Thomas, J. S., Blattberg, R. C., \& Fox, E. J. (2004). Recapturing lost customers. J. Marketing Res., 41(February), 31-45. https://doi.org/10.1509/jmkr.41.1.31.25086

Van Gelder, S. (2003). Global Brand Strategy. Kogan Page, London.

Van Gelder, S. (2003). Global Brand Strategy. Unlocking brand potential across countries, culture and markets. London: Kogan page.

Van Osselaer, S. M. J., \& Alba, J. W. (2003). Locus of equity and brand extension. J. Consumer Res., 29(March), 539-550. https://doi.org/10.1086/346249

Villas-Boas, J. M. (2004). Consumer learning, brand loyalty, and competition. Marketing Sci., 23(1), 134-145. https://doi.org/10.1287/mksc.1030.0044

Wansink, B., \& van Ittersum, K. (2003). Bottoms up! Peripheral cues and consumption volume. J. Consumer Res., 30, 455-463. https://doi.org/10.1086/378621

Yorkston, E. A., \& Menon, G. (2004). A sound idea: Phonetic effects of brand names on consumer judgments. J. Consumer Res., 31(June), 43-51. https://doi.org/10.1086/383422

Zaltman, G. (2003). How Customers Think: Essential Insights into the Mind of the Market. Harvard Business School Press, Boston, MA. 


\section{Macrothink

Zhang, S., \& Schmitt, B. H. (2001). Creating local brands in multilingual international $\begin{array}{llll}\text { markets. } & \text { J. } & \text { Marketing } & \text { Res., }\end{array}$ https://doi.org/10.1509/jmkr.38.3.313.18869

\section{Websites}

http://www.businessweek.com/magazine/content/01_32/b3744001.htm

http://finance.mapsofworld.com/brand/value/siemens.html

http://www.infosys.com/pages/index.aspx http://www.wipro.com/index.htm

http://www.b2binternational.com/b2b-blog/b2b-presentations/free-ebook-the-power-of-indust rial-brands/

\section{Copyright Disclaimer}

Copyright for this article is retained by the author(s), with first publication rights granted to the journal.

This is an open-access article distributed under the terms and conditions of the Creative Commons Attribution license (http://creativecommons.org/licenses/by/3.0/). 